\title{
THE EFFECT OF PLANT QUALITY ON SURVIVAL OF LYMANTRIA DISPAR (LEPIDOPTERA: LYMANTRIIDAE) LARVAE INFECTED BY BACILLUS THURINGIENSIS BERLINER SUBSP. KURSTAKI
}

\author{
YANAR, O. ${ }^{1 *}$ - GÖMEÇ, S. ${ }^{2}$ - TOPKARA, E. F. ${ }^{1}-$ SOLMAZ, G. ${ }^{1}-$ DEMİR, İ. ${ }^{3}$ \\ ${ }^{1}$ Department of Biology, Science and Art Faculty, Ondokuz Mayls University \\ 55139 Samsun, Turkey \\ (phone: +90-362-3121919/5585; fax: +90-362-4576081) \\ ${ }^{2}$ Department of Plant Protection, College of Agriculture, University of Ankara, Ankara, Turkey \\ ${ }^{3}$ Karadeniz Technical University, Faculty of Sciences, Department of Biology \\ 61080 Trabzon, Turkey \\ *Corresponding author \\ e-mail: oyanar46@gmail.com
}

(Received $3^{\text {rd }}$ May 2016; accepted $8^{\text {th }}$ Mar 2017)

\begin{abstract}
In this study the influence of plant secondary compounds on the survival rate of Lymantria dispar (Linnaeus, 1758) which was infected with Bacillus thuringiensis Berliner 1915 subsp. kurstaki was investigated using four different plant species, Elaeagnus rhamnoides (L.) A. Nelson, Quercus cerris L. 1753, Corylus maxima Mill. and Crataegus monogyna Jacq. The highest survival rate was seen on the larvae which fed on the E. rhammoides that had the highest protein rate. The highest mortality rate was seen on the larvae which fed on the C. monogyna that had the lowest protein rate. Maximum deaths of the larvae infected by each food set occurred on the second day. These deaths were observed in larvae that fed on the lowest protein amount plant. We have discovered that survival rate correlated with gallotanen amounts. The survival rate of the larvae infected fed on E. rhammoides that have the highest gallotanen amount were higher than other diets. Our results showed that in the larvae which were treated with Bacillus thuringiensis subsp. kurstaki the survival rate positively correlated with proantosiyanidin (condensed tannin) and total phenolic content.
\end{abstract}

Keywords: secondary compounds, entomopathogen, herbivor, plant-insect interaction, phytophagy

\section{Introduction}

Bacillus thuringiensis (Berliner), which is the most important biopesticide of the world, is a spore-forming, ubiquitous gram-positive bacterium (Zhang et al., 2013). The crystal proteins, which are also called Cry proteins, are parasporal inclusion proteins from $B$. thuringiensis which show toxic effect to a target organism that can be proven through experiments (van Staden, 2015). Infection by pathogens imposes significant fitness costs on hosts, diminishing survival and/or the rate of reproductive output (Moore, 2002). Apart from their direct effects on hosts, pathogen infections are considered to impose significant resource costs related with the maintenance and activation of resistance mechanisms, which may conflict with other life-history traits (Zuk and Stoehr, 2002; Rolff and Siva-Jothy, 2003; Schmid-Hempel, 2005). The ability of the host to fight and withstand infection is related with its nutritional state (Coop and Kyriazakis, 2001).

Lymantria dispar, which is also called the gypsy moth, is among the most harmful phytophagous pest insects of the northern hemisphere. It has a vast capacity to feed on a 
total of more than 500 plant species, including various trees and shrubs (Barbosa et al., 1971). In order to defend against $L$. dispar L., a great number of secondary metabolites of host plants may show strong prooxidative effects on midgut tissue and may cause oxidative stress (Bi and Felton, 1995; Perić-Mataruga et al., 1997; Ilijin et al., 2014; Perić-Mataruga et al., 2014).

Plant-insect interaction shows an endless variation and change which makes this interaction a dynamic system (Mrdaković et al., 2011). Phytophagous insects can use many different host plants across their geographic distribution, but within their environments they usually use a small number of plant species (Ruiz-Montoya et al., 2003). Plants play a significant role in the evolution of insect-pathogen relationships. Host plants can alter the interactions between insect herbivores and their pathogens. Inter- and intra-specific differences in plant chemistry and structure may change the susceptibility of insects to infection and the production and environmental persistence of pathogens (Cory and Hoover, 2006). Host plant quality defines the components of the host plant (e.g., the levels of nitrogen, carbon, trace elements and defensive compounds) that in a positive or negative way have an effect on the performance of herbivorous insects (Awmack and Leather, 2002). A lot of secondary plant metabolites are regarded as strong defense of plants against herbivores and pathogens (Hwang et al., 2008). Reduced insect performance due to poor plant quality can increase the susceptibility of an insect to disease while these same phytochemicals can also diminish the effectiveness of entomopathogens in killing the host (Cory and Hoover, 2006).

This study aims to put forward whether there could be an effect of protein, phenolic and tannin content (hydrolysable and condensed tannin) in plants on the survival of $L$. dispar larvae, which are infected by Bacillus thuringiensis subsp. kurstaki (Btk), when they feed on different plants.

\section{Materials and methods}

\section{The process of obtaining larvae}

The eggs of $L$. dispar were collected from the Cernek lake area, which is within the borders of Kizılirmak Delta in Bafra, Samsun. The eggs were treated with $10 \%$ of sodium hypochlorite and disinfected. Then, they were washed with pure water and put into the refrigerator at a temperature of $5^{\circ} \mathrm{C}$. About 6 months later, the eggs were taken out of the refrigerator and put into the climate cabin that was adjusted to the temperature of $22^{\circ} \mathrm{C}$ and $70 \%$ rate of humidity during a period of 16 hours of light and 8 hours of dark. The larvae that came out of the eggs were put into the plastic containers (sized $5 \mathrm{~cm} \times 10 \mathrm{~cm} \times 2 \mathrm{~cm}$ ) so that there could be 50 larvae in each food group and they were fed with 4 plants that were indicated in the study until the 4th larval period.

\section{The plants to be used during feeding experiment}

In this study, we examined whether the plant quality had any effect on the survival of L. dispar larvae after they were infected by the bacteria. Thus, 4 different plant species, E. rhamnoides, Q. cerris, C. maxima, C. monogyna were used. These plants were collected daily and the larvae fed on them. 


\section{Infection with the bacteria}

In order to infect the larvae with the bacteria, the Btk suspension of $600 \mathrm{~nm}$ wavelength $\left(\mathrm{OD}_{600}\right)$ and with the optical density of 0.189 was obtained from the Department of Biology in Karadeniz Technical University. Btk was isolated and identified by Sevim et al. (2012). Each of the plant sample taken from the 4 plants used in feeding process was treated with $1 \mathrm{ml}$ of Btk suspension. After each leaf in control group was cleansed with $50 \%$ of ethyl alcohol, they were treated with $1 \mathrm{ml}$ of pure/distilled water and put into the containers for the experiment.

\section{Feeding experiment}

The larvae of the 4th period were put into the plastic containers (sized $5 \mathrm{~cm} \times 10 \mathrm{~cm} \times 2 \mathrm{~cm}$ ) so that there could be 45 larvae in each experimental group. Therefore, 60 larvae in total, 15 of which were control groups and others infected by $B t k$, were put in each food group in the experiment. During the feeding experiment, as there were 4 plants, 240 larvae in total were put into the containers. The plastic containers had 5 holes so that the larvae could get air. The control group and the larvae that were infected by the bacteria were fed for 10 days in different incubators that had the same temperature and humidity. During the feeding experiment, each day, a new food was given after it was scaled in assay balance that was sensitive to 0,001 gram and after the remaining food was dried in incubator, their dry weights were scaled.

\section{The process of drying and grinding of leaves}

The leaves were collected from the plant the larvae were fed in order to determine the amount of phenolic, nitrogen, gallotannin and proanthocyanidin in total and for feeding. Then, they were wrapped inside the folio and were dried for 2 months under laboratory conditions and for 5 days in incubator at $50^{\circ} \mathrm{C}$. After the dried leaves were taken out and ground, they were kept in nylon bags.

\section{Plant analysis}

The protein contents of the leaf samples were measured by semi-mikro Kjeldahl method with Kjeltec Auto 1030 analyzer (Tecator, Sweden). The nitrogen content of each sample obtained by Kjeldahl method was multiplied with 6.25 to calculate the total protein content of the plant sample (Monk, 1987). The total phenolic contents of the samples were determined by a method originally used by Swain and Hillis (1959). The method used to determine gallotannin contents of the leaf samples was described by Bate-Smith (1977). Proanthocyanidin contents of the leaf samples were determined spectrophotometrically by a method described by Bate-Smith (1975).

\section{The growth of Btk in nutrient agar with different concentrations of tannic acid}

5 nutrient agars, one of which was for control, containing 1, 3, 7, 10\% of tannic acid concentration were prepared. Btk was inoculated in nutrient agar prepared beforehand. Then, 14 hours of reproduction rates were calculated.

\section{Statistical analyses}

The comparison of the amounts of protein, total phenolic, gallotannin and proanthocyanidin in plants was carried out by using ANOVA Duncan Test. Recording 
to 4 different plants; Kaplan-Meier Survival Analysis Test was used to determine the relationship between the survival rates of the larvae that were infected by the bacteria and the larvae of the control group. The consumption amounts of the larvae in the control group and the larvae infected by Btk were compared by two sample $\mathrm{T}$ test. In this comparison, the data of the survivors was used. In order to compare the effect of the amounts of protein, total phenolic, gallotannin and proanthocyanidin in plants on survival Cox-Regression analysis test was used.

\section{Results}

\section{Chemical composition of the leaf samples}

The total protein contents of the leaf samples were $15.1 \%$ in E. rhamnoides, $10.0 \%$ in $Q$ cerris, $10.9 \%$ in C. maxima and $8.3 \%$ in C. monogyna. According to these results, the highest total protein content was obtained in the leaves of E. rhamnoides; while $C$. monogyna leaves produced the lowest protein content. Protein content of host plant species was found to be different significantly (ANOVA, $F=1577.5, p<0.001$ ).

The gallotannin content of the plant samples observed in the present study was $5.2 \%$ for E. rhamnoides, $2.6 \%$ for $Q$. cerris, $4.3 \%$ for $C$. maximaand $1.8 \%$ for C. monogyna (ANOVA, $F=1508, p<0.001$ ). These results showed that $E$. rhamnoides had much higher gallotannin content in leaves than that of other plant leaves. Total phenolic content of the leaves of E. rhamnoides, $Q$. cerris, $C$. maxima and $C$. monogyna was 10.6, 7.9, 9.9 and $6.2 \%$ respectively. Results from statistical data analysis revealed that host plant species were different significantly in their total phenolic content (ANOVA, $F=3208.7, p<0.001)$. There were significant differences in the proanthocyanidin contents of the leaf samples (ANOVA, $F=11542.5, p<0.001$ ). The proanthocyanidin contents of the leaves from E. rhamnoides, $Q$. cerris, $C$. maxima and $C$. monogyna were $3.9,7.6,11.5$ and $7.2 \%$ respectively.

\section{The growth graphic of Btk in nutrient agar with tannic acid}

In 5 different nutrient agars, by adding an amount of 1, 3, 7 and $10 \%$ of tannic acid and control, the reproduction of bacteria was observed in every other hour and it was found that there was a significant decrease in nutrient agars where tannic acid concentration was $3 \%$ and above. The reproduction graphic according to tannic acid concentration is shown in Figure 1.

\section{The consumption amounts of experimental groups in regard to the plants}

It was found that there was a decrease in the consumption amounts of the larvae infected by the bacteria with regard to the control group. In all 4 plants, there is a significant difference between the larvae in the control group and the larvae infected by the bacteria in terms of consumption amounts. Moreover, the highest consumption amount in control group and in the groups infected by the bacteria was obtained from the larvae feeding on E. rhamnoides. The comparison of the consumption amount of the larvae infected by the bacteria with those in the control groups in terms of food is shown in Table 1. 


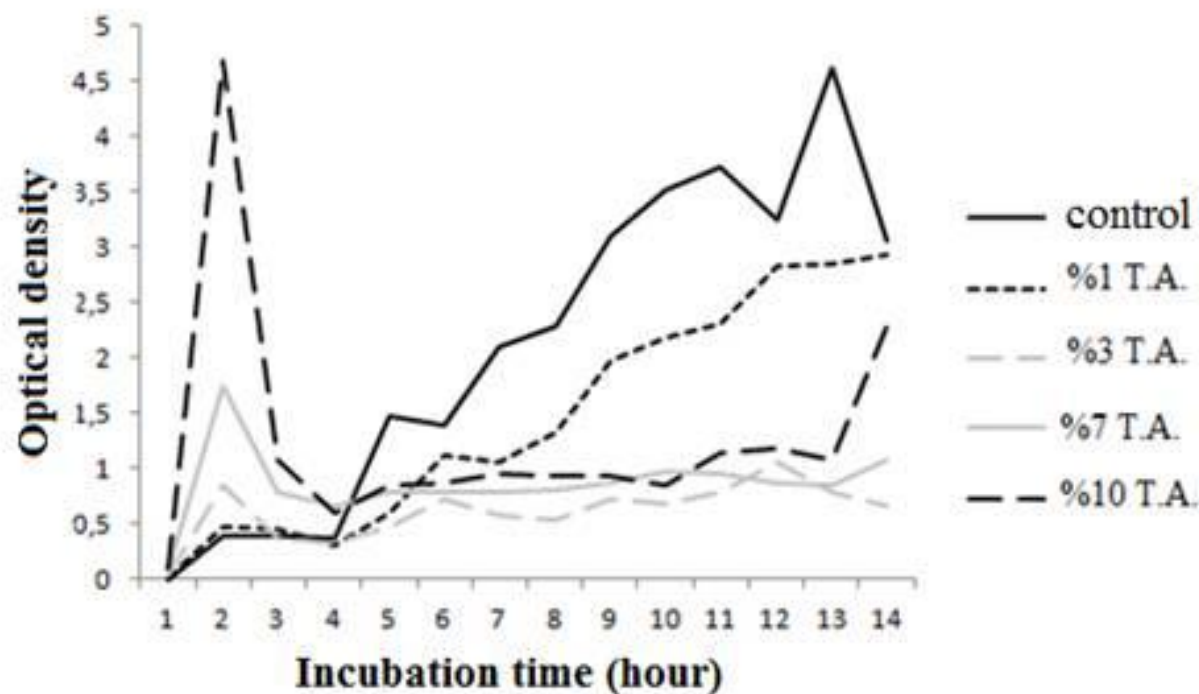

Figure 1. The effect of tannic acid in different concentrations $(1,3,7,10 \%)$ in nutrient agar on the growth of Btk

Table 1. The comparison of the consumption amount of the larvae infected by the bacteria and the larvae in the control groups in terms of food

\begin{tabular}{|c|c|c|c|c|c|}
\hline Plants & $\mathrm{N}$ & Groups & Mean \pm SE & $\mathrm{t}$ & $p$ \\
\hline \multirow{2}{*}{ H. rhamnoides } & 30 & infected & $405.4 \pm 1.5$ & \multirow{2}{*}{-24.0} & \multirow{2}{*}{$<0.001$} \\
\hline & 15 & control & $442.8 \pm 0.8$ & & \\
\hline \multirow{2}{*}{ Q. cerris } & 6 & infected & $311.7 \pm 0.8$ & \multirow[t]{2}{*}{-45.7} & \multirow[t]{2}{*}{$<0.001$} \\
\hline & 13 & control & $417.8 \pm 0.9$ & & \\
\hline \multirow{2}{*}{ C. maxima } & 12 & infected & $265.8 \pm 2.3$ & \multirow{2}{*}{-64.1} & \multirow[t]{2}{*}{$<0.001$} \\
\hline & 14 & control & $394.3 \pm 8.9$ & & \\
\hline \multirow{2}{*}{ C. monogyna } & 3 & infected & 300.8 & & \\
\hline & 12 & control & $416.4 \pm 1.0$ & & \\
\hline
\end{tabular}

\section{The survival analysis of the larvae infected by Btk with regard to food}

It was found that there is an important difference $(p<0.001)$ between the survival rates of the larvae infected by the bacteria with regard to control group. It was found that while the survival rate of the larvae infected by the bacteria is $28.3 \%$, the survival rate of the control group is $90 \%$. The highest survival rate was $66.7 \%$ and it was observed in the larvae feeding on E. rhamnoides. The lowest survival rate was $6.7 \%$ and it was observed in the larvae feeding on C. monogyna. This rate was confirmed as $13.3 \%$ in oak $Q$. cerris plant and as $26.7 \%$ in hazelnut $C$. maxima plant (Fig. 2).

It was found that there is a difference between the survival rates of the larvae infected by the bacteria with regard to plants they fed on. The survival rate of the larvae feeding on E. rhamnoides is different from the larvae feeding on $Q$. cerris and $C$. monogyna $(p<0.05)$ and is different in critical value from the larvae feeding on $C$. maxima (Table 2). 

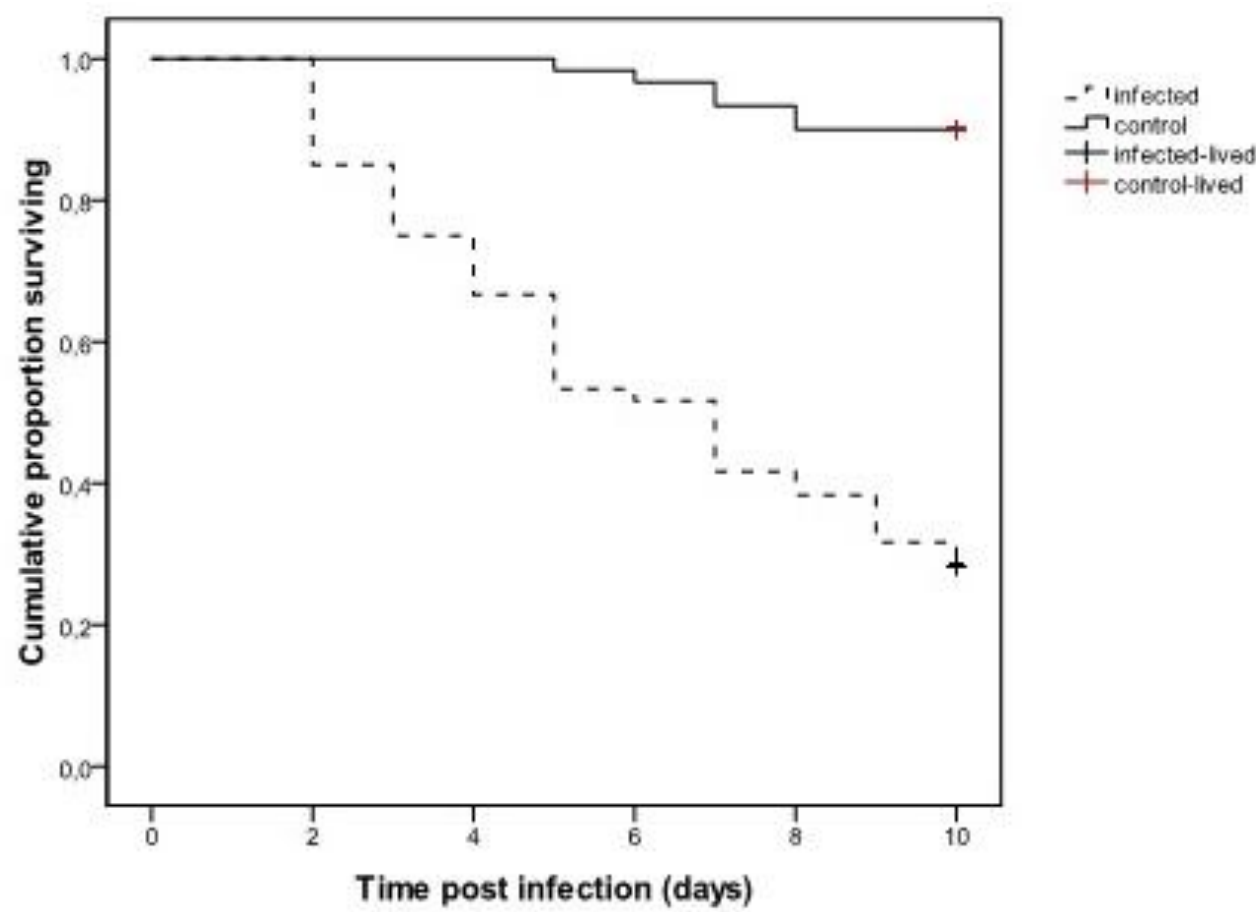

Figure 2. The possibility of cumulative survival of the larvae in the control group and the larvae infected by Btk

Table 2. The comparison of the survival rates of the larvae feeding on the plants infected by the bacteria with regard to plants with Log Rank test

\begin{tabular}{|l|l|l|l|l|l|l|l|l|}
\hline \multirow{2}{*}{ Plants } & \multicolumn{2}{|l|}{ H. rhamnoides } & \multicolumn{2}{l|}{ Q. cerris } & \multicolumn{2}{l|}{ C. maxima } & \multicolumn{2}{l|}{ C. monogyna } \\
\cline { 2 - 9 } & $\begin{array}{l}\text { Chi- } \\
\text { Square }\end{array}$ & $P$ & $\begin{array}{l}\text { Chi- } \\
\text { Square }\end{array}$ & $P$ & $\begin{array}{l}\text { Chi- } \\
\text { Square }\end{array}$ & $P$ & $\begin{array}{l}\text { Chi- } \\
\text { Square }\end{array}$ & $P$ \\
\hline H. rhamnoides & & & 8.104 & 0.004 & 3.672 & 0.055 & 9.716 & 0.002 \\
\hline Q. cerris & 8.104 & 0.004 & & & 0.952 & 0.329 & 0.185 & 0.667 \\
\hline C. maxima & 3.672 & 0.055 & 0.952 & 0.329 & & & 1.771 & 0.183 \\
\hline C. monogyna & 9.716 & 0.002 & 0.185 & 0.667 & 1.771 & 0.183 & & \\
\hline
\end{tabular}

The Effect of Protein and Secondary Compounds on the Survival of the Larvae Infected by Btk

According to Cox-Regression analysis results, protein, proanthocyanidin and total phenolic have a positive effect. Infection by the bacteria increases death risk 200 -fold. Cox-Regression analysis results are shown in Table 3. 
Table 3. The comparison of the effect of protein and secondary compounds on the survival of the larvae infected by Btk with Cox-Regression analysis

\begin{tabular}{|l|c|r|r|r|r|r|}
\hline & \multicolumn{1}{|c|}{$\mathrm{B}$} & \multicolumn{1}{c|}{$\mathrm{SE}$} & Wald & \multicolumn{1}{c|}{$d f$} & \multicolumn{1}{c|}{$P$} & \multicolumn{1}{|c|}{$\operatorname{Exp}(\mathrm{B})$} \\
\hline Infected by Btk & 5.303 & 1.156 & 21.048 & 1 & .000 & 200.849 \\
Protein & -1.339 & 0.322 & 17.243 & 1 & .000 & 0.262 \\
Total phenolics & -0.239 & 0.036 & 43.988 & 1 & .000 & 0.787 \\
Gallotannin & -0.351 & 0.065 & 29.184 & 1 & .000 & 0.704 \\
Proanthocyanidin & -0.643 & 0.155 & 17.250 & 1 & .000 & 0.526 \\
\hline
\end{tabular}

\section{Discussion}

The results show that the protein amount in the plant, which the insect infected by the bacteria feeds on, has a positive effect on its survival. The highest survival rate in the larvae infected by Btk has been obtained from the larvae feeding on E. rhamnoides containing the highest protein amount. The highest mortality has been found in the larvae feeding on $C$. monogyna containing the lowest protein amount. These results put forward that protein has an important role in L. dispar's immune system to be strong. Kleiner et al. (1998) have indicated that when $L$. dispar larvae that are infected by $B$. thuringiensis are fed on hybrid Populus plants, the mortality of the larvae feeding on the plants with higher protein amounts decreases.

This insect feeds on a wide range of plants which contain allelochemicals, such as phenolics, tannins, and terpenoids and a great number of these allelochemicals are toxic to bacteria (Broderick et al., 2004; Dillon and Dillon, 2004). In a host, selection pressure on the microbial community may be caused by toxic compounds. The compounds that would otherwise be toxic to the insect are degraded and metabolized by the surviving bacteria (Broderick et al., 2004). When each food group is considered, it can be clearly seen that the consumption amount of the larvae in control group is higher than the infected larvae. The highest consumption amount among the infected larvae has been observed in the larvae feeding on E. rhamnoides. The protein amount of this plant is higher than the other plants in experimental group. This is also the plant that has the lowest mortality. Therefore, this consequence emphasizes the significance of protein for an infected insect.

Appel and Schultz (1994) conclude that oak tannins reduce the effectiveness of this B. thuringiensis formulation (Thuricide), that stand composition may have a major effect on the effectiveness of microbial control measures, and that tannin inhibition may represent a useful target for formulation. In this study, the high survival rate of the larvae infected by Btk can be associated with the excess of hydrolysable tannin concentration. When tannic acid concentration which are added to Btk's nutrient agar increases, the bacteria reproduction decreases, which supports the argument of this study. Unlike our findings, Gibson et al. (1995) found that tannic acid caused an increase in the efficacy of $B$. thuringiensis subsp. kurstaki against Heliothis virescens $\mathrm{F}$. and Trichoplusia ni (Hübner) larvae.

Interactions between plants and herbivores are mediated by plant chemicals (Bednarek, 2012; Mithöfer and Boland, 2012). For instance, in defense against specialist insects, tannins are specifically important as digestibility-reducing compounds 
(Forkner et al., 2004; Müller-Schärer et al., 2004). Tanniferous plants which have relatively low levels of protein would be more deterrent to herbivores with the same levels (Barbehenn and Constabel, 2011). In this study, the highest survival rate of the larvae infected with Btk was obtained from the larvae feeding on E. rhamnoides. This plant has the highest amount of gallotannin. The larvae feeding on C. maxima have both a high survival rate and a high amount of gallotannin.

Different toxins have been proven to be active against a great number of insects; however, in general, each toxin is restricted to a few species within one insect order in terms of action (Raymond et al., 2007). The growth of various bacteria including Listeria monocytogenes, Escherichia coli, Bacillus subtilis, Lactobacillus spp., and Staphylococcus aureus are inhibited by phenolic acids (Cueva et al., 2010; Ramos-Nino et al., 1996; Sánchez-Maldonado et al., 2011; Wen et al., 2003). A strong negative correlation was found between larval performance of a specialist caterpillar (Gadirtha inexacta) and tannins content (Huang et al., 2010; Wang et al., 2012). On the contrary, results of this study show that the survival rate of the larvae infected by $B t k$ is correlated positively with condensed tannins.

Appel and Schultz (1994) suggest that mortality was correlated negatively with the concentration of total phenolic, gallotannin and protein binding activity in leaves. It was found that total phenolic amount has a negative effect on the survival rate of the larvae infected by bacteria. This may be the result of high mortality in the larvae feeding on $C$. maxima which contains a high amount of phenolic. However, the survival rate is high in the larvae infected by bacteria feeding on E. rhamnoides containing the highest total phenolic amount when compared with the larvae feeding on other plants. In a previous study, it has been suggested that plant-derived chemicals cross the midgut or initiate signaling cascades, which alter host physiology sufficiently to impact normal immune function, or reduce cell permissiveness to infection (Lee et al., 2006). The results of this study suggest that the chemicals in the content of total phenolic can alter the answer.

Studies on entomopathogenic bacteria focused on finding their efficacy in terms of lethal concentration and killing speed (Deilamy and Abbasipour, 2013), their susceptibility of different stages of larval development to the pathogen (Erb et al., 2001; Gilliland et al., 2002) and the efficacy of sublethal effects on larval development (Mohan et al., 2008). Significant reductions were found in pupal weight, larval weight, normal pupation and prolonged larval period of Heliothis armigera Hübner (Lepidoptera: Noctuidae) larvae fed on sublethal doses of B. thuringiensis (Mohan et al., 2008). In this study, bacteria intensity was reduced by subtilizing 10 -fold less than normal dose for infection. The role of $B$. thuringiensis spores eaten by the larvae can immensely alter in terms of bacteria intensity, bacteria type, the concentration of Cry toxins, different combinations and species (Hansen and Salamitou, 2000).

In conclusion, the negative impact of entomopathogens on insects is obvious. Insects aren't vulnerable to entomopathogens. In this study, even though the impact of secondary compounds and protein in plants on defense against entomopathogens is emphasized, this correlation is complicated. Broderick et al. (2006) reported that $B$. thuringiensis did not kill larvae of the gypsy moth in the absence of indigenous midgut bacteria. They suggested that the enteric bacteria might remove an immunological barrier, such as defensive enzymes or antimicrobial peptides that prevent growth of B. thuringiensis. Midgut bacteria affect the insect survival rate. Therefore, it may be much useful to think of a synergistic effect rather than the mere effect of secondary compounds and protein in plants. Further researches about this argument will set a much clear frame. 
Acknowledgements. This study was supported by the Ondokuz Mayis University Research Foundation (PYO.FEN.1904.11.027).

\section{REFERENCES}

[1] Appel, H.M., Schultz, J.C. (1994): Oak tannins reduce effectiveness of thuricide (Bacillus thuringiensis) in the gypsy moth (Lepidoptera: Lymantriidae). - Journal of Economic Entomology 87: 1736-1742.

[2] Awmack, C.S., Leather, S. R. (2002): Host plant quality and fecundity in herbivorous insects. - Annual Review of Entomology 47: 817-844.

[3] Barbehenn, R.V., Constabel, P.C. (2011): Tannins in plantherbivore interactions. Phytochemistry 72: 1551-1565.

[4] Barbosa, P.P., Martinat, P., Waldvogel, M. (1971): Development, fecundity and survival of the herbivore Lymantria dispar and the number of plant species in its diet. - Ecological Entomology 11: 1-6.

[5] Bate-Smith, E.C. (1975): Phytochemistry of proanthocyanidins. - Phytochemistry 14: 1107-1113.

[6] Bate-Smith, E.C. (1977): Astringent tannins of Acer species. - Phytochemistry 16: 23312336.

[7] Bednarek, P. (2012): Chemical warfare or modulators of defence responses: the function of secondary metabolites in plant immunity. - Current Opinion in Plant Biology 15: 407414.

[8] Bi, J.L., Felton, G.W. (1995): Foliar oxidative stress and insect herbivory: Primary compounds, secondary metabolites, and reactive oxygen species as components of induced resistance. - Journal of Chemical Ecology 21: 1511-1530.

[9] Broderick, N.A., Raffa, K.F., Goodman, R.M., Handelsman, J. (2004): Census of the bacterial community of the gypsy moth larval midgut by using culturing and culture independent methods. - Applied and Environmental Microbiology 70: 293-300.

[10] Broderick, N.A., Raffa, K.F., Handelsman, J. (2006): Midgut bacteria required for Bacillus thuringiensis insecticidal activity. - Proceedings of the National Academy of Sciences 103: 15196-15199.

[11] Coop, R.L., Kyriazakis, I. (2001): Influence of host nutrition on the development and consequences of nematode parasitism in ruminants. - Trends in Parasitology 17 (7): 325330.

[12] Cory, J.S., Hoover, K. (2006): Plant-mediated effects in insect-pathogen interactions. Ecology and Evolution 21(5): 278-286.

[13] Cueva, C., Moreno-Arribas, M.V., Martinez-Alvarez, P.J., Bills, G., Vicente, M.F., Basilio, A., et al. (2010): Antimicrobial activity of phenolic acids against commensal, probiotic and pathogenic bacteria. - Research in Microbiology 161: 372-382.

[14] Deilamy, A., Abbasipour, H. (2013): Comparative bioassay of different isolates of Bacillus thuringiensis subsp. kurstaki on the third larval instars of diamondback moth, Plutella xylostella (L.) (Lep.: Plutellidae). - Archives of Phytopathology and Plant Protection 46: 1480-1487.

[15] Dillon, R.J., Dillon V.M. (2004): The gut bacteria of insects: Nonpathogenic interactions. - Annual Reviews of Entomology 49: 71-92.

[16] Erb, S.L., Bourchier, R.S., Frankenhuyzen, K.V., Smith, S.M. (2001): Sublethal effects of Bacillus thuringiensis berliner subsp. kurstaki on Lymantria dispar (Lepidoptera: Lymantriidae) and the tachinid parasitoid Compsilura concinnata (Diptera: Tachinidae). Environmental Entomology 30: 1174-1181.

[17] Forkner, R.E., Marquis, R.J., Lill, J.T. (2004): Feeny revisited: Condensed tannins as anti-herbivore defences in leaf-chewing herbivore communities of Quercus. - Ecological Entomology 29: 174-187. 
[18] Gibson, D.M., Gallo, L.G., Krasnoff, S.B., Ketchum, R.E. (1995): Increased efficacy of Bacillus thuringiensis subsp. kurstaki in combination with tannic acid. - Journal of Economic Entomology 88: 270-277.

[19] Gilliland, A., Chambers, C.E., Bone, E.J., Ellar, D.J. (2002): Role of Bacillus thuringiensis Cry1 endotoxin binding in determining potency during lepidopteran larval development. - Applied and Environmental Microbiology 68: 1509-1515.

[20] Hansen, B.M., Salamitou, S. (2000): Virulence of Bacillus thuringiensis. - In: Charles, J.F., Delécluse, A., Roux, C.N. (ed.) Entomopathogenic Bacteria: from Laboratory to Field Application, Klewer Academic Publishers, London, 46.

[21] Huang, W., Siemann, E., Wheeler, G.S., Zou, J., Carrillo, J., Ding, J. (2010): Resource allocation to defence and growth are driven by different responses to generalist and specialist herbivory in an invasive plant. - Journal of Ecology 98: 1157-1167.

[22] Hwang, S., Liu, C., Shen, T. (2008): Effects of plant nutrient availability and host plant species on the performance of two Pieris butterflies (Lepidoptera: Pieridae). Biochemical Systematics and Ecology 36: 505-513.

[23] Ilijin, L., Vlahović, M., Perić-Mataruga, V., Kmetič, I., Gavrilović, A., Matić, D., Mrdaković, M. (2014): Temperature-induced stress response in Lymantria dispar neurosecretory neurons. - Turkish Journal of Biology 38: 157-167.

[24] Kleiner, K.W., Raffa, K.F., Ellis, D.D., McCown, B.H. (1998): Effect of nitrogen availability on the growth and phytochemistry of hybrid poplar and efficacy of the Bacillus thuringiensis cry1A (a) d-endotoxin on gypsy moth. - Canadian Journal of Forest Research 28(7): 1055-1067.

[25] Lee, K.P., Cory, J.S., Wilson, K., Raubenheimer, D., Simpson, S.J. (2006): Flexible diet choice offsets protein costs of pathogen resistance in a caterpillar. - Proceedings of the Royal Society 273: 823-829.

[26] Mithöfer, A., Boland, W. (2012): Plant defense against herbivores: Chemical aspects. Annual Review of Plant Biology 63: 431-450.

[27] Mohan, M., Sushil, S.N., Bhatt, J.C., Gujar, G.T., Gupta, H.S. (2008): Synergistic interaction between sublethal doses of Bacillus thuringiensis and Campoletis chlorideae in managing Helicoverpa armigera. - BioControl 53: 375-386.

[28] Monk, C. D. (1987): Sclerophylly in Quercus virginiana Mill. - Castanea, 52(4): 256261.

[29] Moore, J. (2002): Parasites and the Behavior of Animals. - Oxford University Press, Oxford, UK, 315.

[30] Mrdaković, M., Mataruga, V.P., Ilıjın, L., Vlahović, M., Todorović, D., Nenadović, V., Lazarević, J. (2011): The effects of tannic acid on the fitness-related traits of Lymantria dispar L. larvae. - Archives of Biological Sciences 63(4): 1037-1045.

[31] Müller-Schärer, H., Schaffner, U., Steinger, T. (2004): Evolution in invasive plants: Implications for biological control. - Trends in Ecology \& Evolution- Cell 19: 417-422.

[32] Perić-Mataruga, V., Blagojević, D., Spasić, M.B., Ivanović, J., Janković-Hladni, M. (1997): Effect of the host plant on the antioxidative defence in the midgut of Lymantria dispar L. caterpillars of different population origins. - Journal of Insect Physiology 43: 101-106.

[33] Perić-Mataruga, V., Vlahović, M., Mrdaković, M., Todorović, D., Matić, D., Gavrilović, A., Ilijin, L. (2014): Prothoracicotropic hormoneproducing neurosecretory neurons and antioxidative defense in midgut of Lymantria dispar in trophic stress. - Turkish Journal of Biology 38: 403-411.

[34] Ramos-Nino, M.E., Clifford, M.N., Adams, M.R. (1996): Quantitative structure activity relationship for the effect of benzoic acids, cinnamic acids and benzaldehydes on Listeria monocytogenes. - Journal of Applied Bacteriology 80: 303-310.

[35] Raymond, B., Davis, D., Bonsall, M.B. (2007): Competition and reproduction in mixed infections of pathogenic and non-pathogenic Bacillus spp. - Journal of Invertebrate Pathology 96: 151-155. 
[36] Rolff, J., Siva-Jothy, M.T. (2003): Invertebrate ecological immunology. - Science 301: $472-475$.

[37] Ruiz-Montoya, I., Nunez-Farfan, J., Vargas J. (2003): Host associated genetic structure of Mexican populations of the cabbage aphid Brevicoryne brassicae L. (Homoptera: Aphididae). - Heredity 91: 415-421.

[38] Sánchez-Maldonado, A.F., Schieber, A., Gänzle, M.G. (2011): Structure-function relationship of the antibacterial activity of phenolic acids and their metabolism by lactic acid bacteria. - Journal of Applied Microbiology 111(5): 1176-1184.

[39] Schmid-Hempel, P. (2005): Evolutionary ecology of insect immune defenses. - Annual Review of Entomology 50: 529-551.

[40] Sevim, A., Eryüzlü, E., Demirbag, Z., Demir, I. (2012): A Novel cry2Ab Gene from the Indigenous Isolate Bacillus thuringiensis subsp. kurstaki. - Journal of Microbiology and Biotechnology 22: 137-144.

[41] Swain, T., Hillis, W. E. (1959): The phenolic constituents of Prunus domestica. - Journal of the Science of Food and Agriculture 10: 63-68.

[42] van Staden, M. (2015): The role of gut microbes on the efficacy of Bt maize against lepidopteran stem borers. - Dissertation submitted in fulfilment of the requirements for the degree Magister Scientiae in Environmental Sciences at the Potchefstroom Campus of the North-West University.

[43] Wang, Y., Siemann, E., Wheeler, G.S., Zhu, L., Gu, X., Ding, J. (2012): Genetic variation in anti-herbivore chemical defences in an invasive plant. - Journal of Ecology 100: 894904.

[44] Wen, A., Delaquis, P., Stanich, K., Toivonen, P. (2003): Antilisterial activity of selected phenolic acids. - Food Microbiology 20: 305-311.

[45] Zhang, L., Qıu, S., Huang, T., Huang, Z., Xu, L., Wu, C., Gelbıč, I., Guan, X. (2013): Effect of chemical additives on Bacillus thuringiensis (Bacillales: Bacillaceae) against Plutella xylostella (Lepidoptera: Pyralidae). - Journal of Economic Entomology 106(3): 1075-1080.

[46] Zuk, M., Stoehr, A.M. (2002): Immune defense and host life history. - The American Naturalist 16: 9-22. 